\title{
DAMPAK IMPLEMENTASI PENDIDIKAN INKLUSI TERHADAP ASPEK AKADEMIK SISWA LAMBAN BELAJAR (SLOW LEARNER)
}

\author{
Suparno, N. Praptiningrum, dan Ernisa Purwandari \\ Universitas Negeri Yogyakarta \\ e-mail: suparno@uny.ac.id
}

\begin{abstract}
Abstrak
Pendidikan inklusi sebagai sebuah pendekatan untuk memenuhi kebutuhan pendidikan belajar semua anak, menjadi solusi bagi peserta didik berkebutuhan khusus untuk mendapatkan layanan pendidikan setara dengan peserta didik pada umumnya termasuk siswa berkebutuhan khusus lamban belajar (slow learner). Daerah Istimewa Yogyakarta (DIY) sebagai salah satu provinsi penyelenggara pendidikan inklusi telah menerapkan pendidikan inklusi di semua kabupaten dan kota. Kajian ini penting untuk memperbaiki praktik pendidikan inklusi di DIY selanjutnya. Subjek dalam penelitian ini adalah siswa lamban belajar (slow learner) tingkat dasar (dasar 1-3) di tujuh SD Inklusi di Bantul. Hasil penelitian menunjukkan bahwa 1) implementasi pendidikan inklusi memberikan dampak positif terhadap capaian akademik membaca dan aritmatika siswa lamban belajar; 2) implementasi pendidikan inklusi belum menunjukkan dampak yang positif terhadap capaian akademik menulis siswa lamban belajar. Penelitian masih terbatas pada siswa lamban belajar sehingga perlu pengkajian lebih lanjut akan dampak pendidikan inklusi pada siswa berkebutuhan khusus lainnya.
\end{abstract}

Kata kunci: aspek akademik, aspek non akademik, lamban belajar

\section{THE IMPACT OF THE IMPLEMENTATION OF INCLUSIVE EDUCATION ON ACADEMIC ASPECTS OF STUDENTS SLOW RESPON}

\begin{abstract}
Inclusive education as an approachment to meet the needs of learning all children be a solution for students with special needs to get the services of education equivalent to students in general included in it students slow learner. Daerah Istimewa Yogyakarta (DIY) as one of the provinces of the organizers inclusive education in all of the regency and the city. This study is an important to improve the practice of inclusive education in DIY next time. The subject in this research are students with slow learner the basic (basic 1-3) in seventh inclusive elementary school in Bantul. The results of the research indicate that 1) implementation inclusive education give a positive impact on their academic reading and arithmetical students with slow learner; 2) implementation inclusive education has not shown a positive impact on their academic wrote students with slow learner. The research is still limited on the students with slow learner so that need to more assessment will be the impact of inclusive education on the other students with special needs.
\end{abstract}

Keywords: aspect of the academic, aspect of the a academic, slow learner

\section{PENDAHULUAN}

Perkembangan dunia pendidikan bagi anak berkebutuhan khusus di Indonesia mulai berwarna sejak pemerintah mengeluarkan Undang-Undang Nomor 20 tahun 2003 tentang Sistem Pendidikan Nasional yang kemudian diperbaharui dalam Peraturan Menteri Pendidikan Nasional (Permendiknas) nomor 70 Tahun 2009. Permendiknas nomor 70 tahun 2009 menyebutkan bahwa pendidikan inklusi sebagai sistem penyelenggaraan pendidikan yang memberikan kesempatan kepada semua peserta didik yang memiliki kelainan 
dan memiliki potensi kecerdasan dan/atau bakat istimewa untuk mengikuti pendidikan atau pembelajaran dalam lingkungan pendidikan secara bersama-sama dengan peserta didik pada umumnya.

Konsep inklusi yang memberikan kesempatan peserta didik berkebutuhan khusus untuk belajar bersama dengan peserta didik tidak serta merta menggabungkan mereka dalam satu kelas ataupun dalam satu sekolah. Peserta didik berkebuhan khusus memerlukan akomodasi dalam pendidikan sesuai kebutuhannya. Maksudnya, untuk dapat belajar bersamasama dengan siswa pada umumnya, siswa berkebutuhan khusus membutuhkan peralatan khusus, teknik khusus, pendekatan/ metode pembelajaran khusus, pengaturan lingkungan secara khusus dan lain sebagainya. Akomodasi ini disesuaikan dengan kebutuhan masing-masing siswa sehingga memungkinkan siswa untuk berpartisipasi penuh dalam kegiatan belajar bersama siswa pada umumnya salah satunya pada siswa lamban belajar (slow learner).

Siswa lamban belajar merupakan siswa yang memiliki IQ 70-90 sehingga kesulitan untuk mencapai hasil belajar sesuai dengan capaian kelompok usia sebaya. Kebutuhan khusus siswa lamban belajar adalah penyesuaian atau adaptasi beberapa aspek program pembelajaran (). Selain akomodasi terhadap kebutuhan khusus, siswa lamban belajar juga memerlukan aksesibilitas.

Aksesibilitas adalah kemudahan yang disediakan bagi penyandang disabilitas guna mewujudkan kesamaan kesempatan dalam segala aspek kehidupan dan penghidupan. Salah satu aksesibilitas yang diperlukan siswa lamban belajar adalah aksesibilitas dalam pembelajaran.

Permasalahan yang terkait dengan aksesibilitas dalam pembelajaran yang umum terjadi di sekolah inklusi menurut Schools Improvement (Wehmeyer, Agran, \& Hughes, 2000) diantaranya 1) anak pasif, tidak didorong secara aktif, jumlah murid yang terlalu banyak dalam satu kelas; 2) Pembelajaran yang buruk: terlalu ketat, mutu pelatihan guru yang buruk, tidak responsive terhadap kebutuhan anak; 3) Sistem yang kaku dan tidak tepat sebagai warisan penjajah dan tekanan dari negara donor; 4) Membaca permulaan dan keterampilan dasar tidak diajarkan dengan memadahi.

Gubernur DIY telah mendeklarasikan DIY sebagai daerah pendidikan inklusi pada 12 Desember 2014 dengan didukung Bupati dan Walikota se DIY. Deklarasi ini memberikan kesempatan siswa lamban belajar untuk belajar di sekolah regular. Hal ini sejalan dengan hasil penelitian MacMillan, Gresham, Bocian, \& Lambros (1998) yang menyebutkan bahwa siswa lamban belajar tidak cocok dengan sistem pendidikan khusus (SLB) dan umumnya belajar di sekolah normal (sekolah inklusi). Oleh karena itu perlu dilakukan kajian mengenai dampak pendidikan inklusi terhadap aspek akademik terhadap siswa lamban belajar di SD Inklusi di Kabupaten Bantul DIY. Kajian ini penting sebagai dasar untuk memperbaiki praktik pendidikan inklusi di DIY selanjutnya.

\section{METODE}

Jenis penelitian yang digunakan adalah expost-facto dengan menggunakan pendekatan survei melalui teknik observasi terhadap sampel berdasarkan informasi yang teramati, sesuai dengan panduan instrumen yang telah dikembangkan. Penelitian ini merupakan penelitian ex-post facto, dengan menggunakan pendekatan penelitan survey, dengan memberi jawaban atas pertanyaan/pernyataan angket yang diberikan untuk guru. Data yang telah terkumpul selanjutnya diolah dan dianalisis secara deskriptif analitik, mula-mula data data dianalisis secara deskriptif dan selanjutnya dianalisis secara statistik deskriptif dengan prosentase.

Populasi dalam penelitian ini adalah semua siswa lamban belajar (slow learner) kelas dasar 1-3 yang ada di wilayah Bantul, Daerah Istimewa Yogyakarta. Adapun sebaran populasinya mencakup tujuh SD Inklusi baik negeri maupun swasta di Daerah Istimewa Yogyakarta. 


\section{HASIL DAN PEMBAHASAN}

\section{Hasil}

Aspek akademik yang menjadi fokus dalam penelitian ini adalah membaca, menulis, dan Matematika. Pengembangan instrumen aspek membaca permulaan, aspek menulis permulaan, sementara untuk Matematika mengikuti tahapan aritmatika yang dikemukakan oleh Brueckner \& Bond (MacMillan, Gresham, Bocian, \& Lambros, 1998). Instrumen tersebut digunakan untuk melakukan tes kemampuan akademik anak lamban belajar di Kabupaten Bantul, DIY.

Penelitian dilakukan pada semua anak lamban belajar kelas dasar 1 sampai 3 di tujuh sekolah dasar negeri di Kabupaten Bantul. Jumlah subjek dalam penelitian ini adalah 75 siswa dengan rincian 21 siswa kelas 1, 28 siswa kelas 2, dan 26 siswa kelas 3. Pelaksanaan tes akademik dimulai pada awal Oktober 2017 ketika siswa selesai menjalani ujian tengah semester. Pelaksanaan menunggu ujian tengah semester mengingat penelitian dilaksanakan semester gasal sehingga tidak memungkinkan untuk melakukan tes akademik di awal semester.

Adapun grafik hasil tes kemampuan membaca permulaan siswa kelas 1-3 secara keseluruhan adalah sebagai berikut.

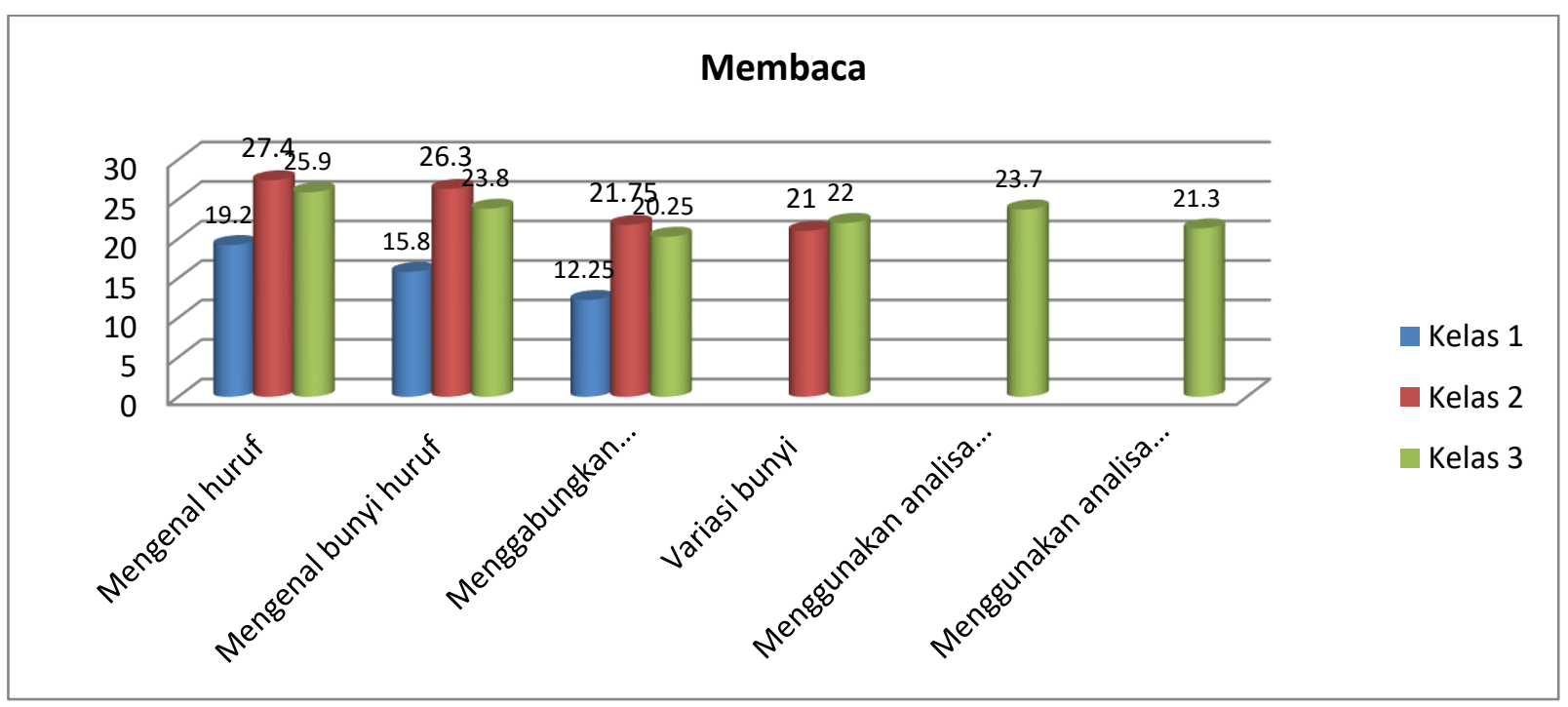

Gambar 1. Hasil tes akademik membaca permulaan kelas 1-3

Gambar tersebut menunjukkan bahwa dari 21 siswa kelas $1,19.2$ di antaranya mampu mengenal huruf, $15.8 \mathrm{di}$ antaranya mampu mengenal bunyi huruf, dan 12.5 mampu menggabungkan bunyi menjadi kata. Kemampuan membaca kelas 2 yang berjumlah 28 siswa berdasarkan grafik tersebut adalah 27.4 mampu mengenal huruf, 26.3 mampu mengenal bunyi huruf, 21.75 mampu menggabungkan bunyi menjadi kata, dan 21 di antaranya mampu membaca variasi bunyi. Sementara untuk kelas 3 yang berjumlah 26 siswa, 25.9 di antaranya mampu mengenal huruf, 23.8 mampu mengenal bunyi huruf, 20.25 mampu menggabungkan bunyi huruf, 22 mampu membaca variasi bunyi, 23.7 mampu menggunakan analisa konteks, dan 21.3 mampu menggunakan analisa struktural.

Hasil tes kemampuan menulis permulaan siswa lamban belajar secara umum dapat dilihat pada grafik berikut: 


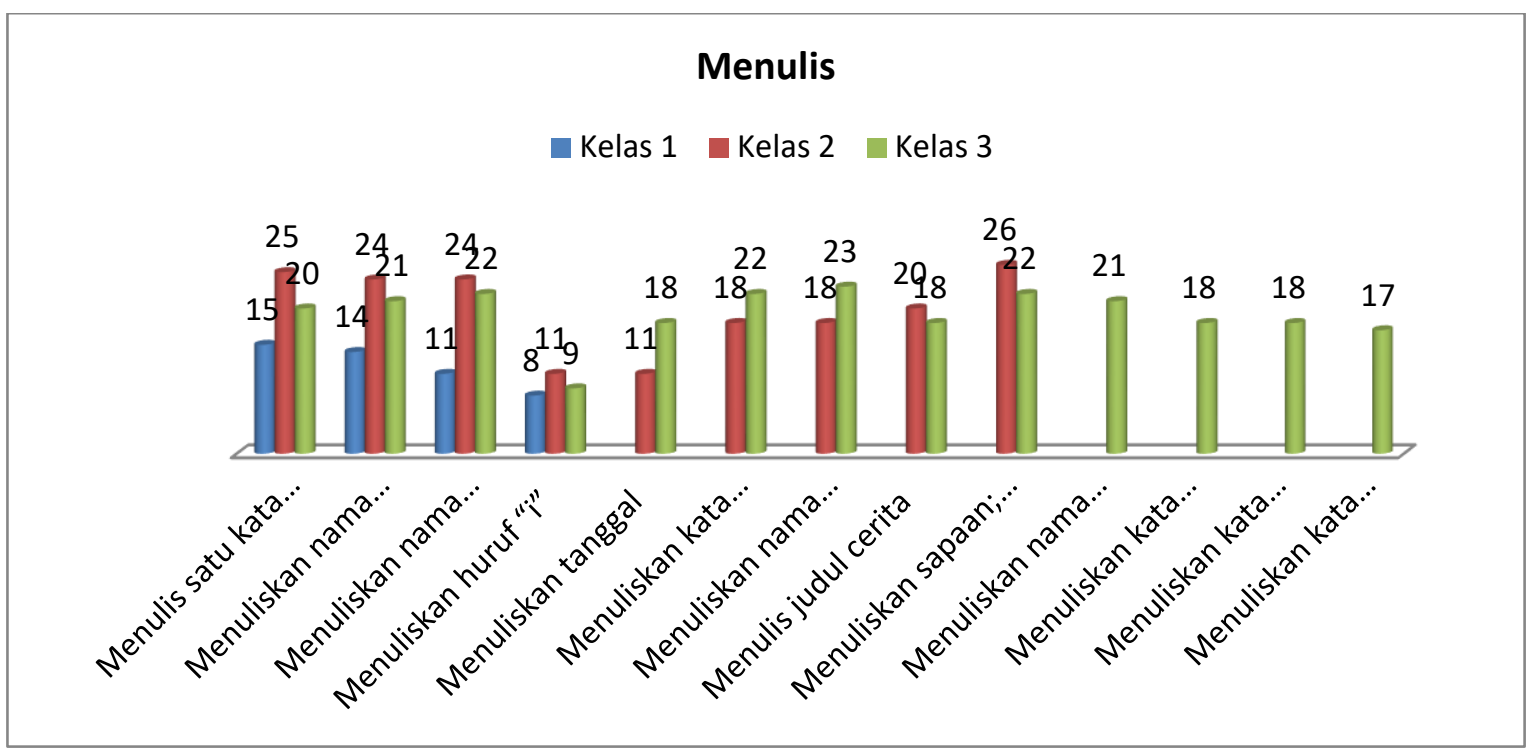

Gambar 2. Hasil tes akademik menulis permulaan kelas 1-3

Berdasarkan grafik tersebut dapat diketahui bahwa kemampuan menulis siswa kelas 1 masih di bawah rata-rata. Rerata kemampuan menyalin kata yang dilihat 15 ; menuliskan nama sendiri 14; menuliskan nama guru, nama sekolah, dan alamat rumah 11, dan menuliskan huruf i besar dan kecil berada direrata 8 dari 21 siswa yang menjadi subjek penelitian. Rerata terendah pada kemampuan membedakan menulis huruf i kapital dan I kecil. Hal yang menjadi sorotan di sini adalah kemampuan anak dalam menuliskan namanya sendiri. Sebagian besar siswa belum mampu menuliskan namanya sendiri dan memerlukan bimbingan tester untuk menuliskan namanya.

Berbeda dengan siswa kelas 1, rerata kemampuan siswa kelas 2 sebagian besar sudah berada di atas rata-rata. Rerata rendah berada pada komponen menuliskan huruf i dan juga menuliskan tanggal. Sebagian besar siswa menuliskan tanggal dari tahun dulu baru tanggal, selain itu dalam menuliskan tanggal hanya menuliskan tahunnya saja.

Hasil tes kemampuan aritmatika siswa lamban belajar kelas 1-3 adalah sebagai berikut:

\section{Aritmatika}

Kelas 1 Kelas 2 Kelas 3

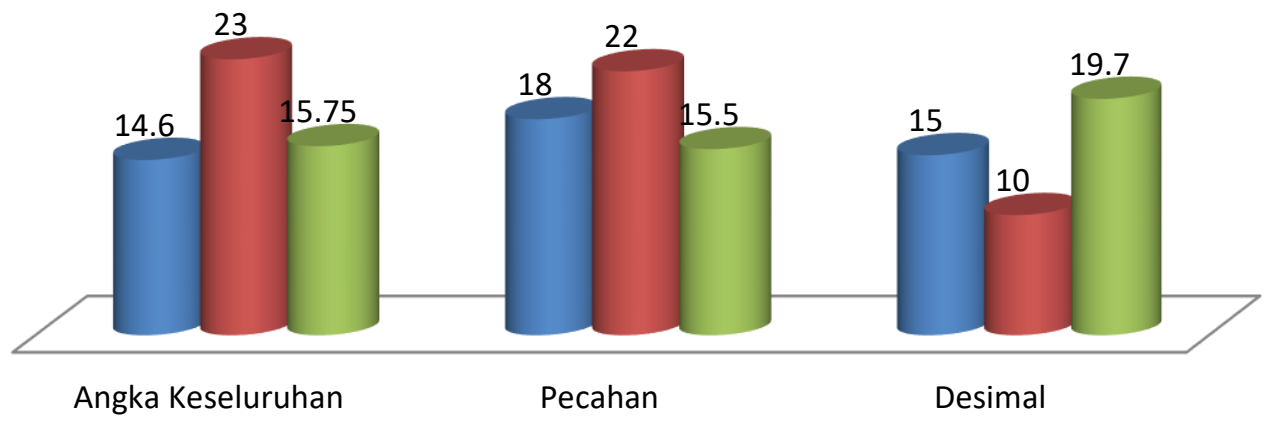

Gambar 3. Hasil tes akademik aritmatika kelas 1-3 
Tampak dari gambar di atas bahwa kemampuan aritmatika siswa lamban belajar masih rendah. Kemampuan rendah nampak pada aspek desimal. Berdasarkan analisis hasil tes, sebagian besar siswa kelas 1 dan 2 belum mampu dalam mengidentifikasi nilai tempat. Sementara siswa kelas 3 relatif tidak memiliki hambatan dalam aspek desimal.

Secara keseluruhan, bisa dikatakan siswa lamban belajar tidak mengalami permasalahan yang berarti di aspek akademik. Keberhasilan ini tidak lepas dari upaya yang dilakukan guru, sekolah, maupun orang tua. Upaya tersebut di antaranya a) Menyediakan guru pendamping khusus baik yang dibiayai orang tua, sekolah, maupun pemerintah; b) Merespon gaya belajar anak; c) Memberikan remedial; d) Menggunakan media yang disukai anak; e) Membentuk kelompok sebagai tutor teman sebaya; dan f) Mengomunikasikan dengan orang tua.

\section{Pembahasan}

Hasil penelitian menunjukkan bahwa implementasi pendidikan inklusi memberikan dampak positif bagi siswa lamban belajar baik pada aspek akademik. Keberhasilan tersebut sesuai dengan hasil temuan MacMillan, Gresham, Bocian, \& Lambros (1998, 83-94) yang menyebutkan bahwa siswa lamban belajar tidak cocok dengan sistem pendidikan khusus (SLB) dan umumnya belajar di sekolah normal (sekolah inklusi). Keberhasilan ini tidak lepas dari peran berbagai pihak di antaranya pemerintah, sekolah, guru, dan juga orang tua.

Upaya yang dilakukan pemerintah, sekolah, guru, dan juga orang tua sejalan dengan upaya yang dilakukan dalam Schools Improvement (Wehmeyer, Agran, $\&$ Hughes, 2000). Adapun upaya yang dilakukan Schools Improvement (Wehmeyer, Agran, \& Hughes, 2000) adalah sebagai berikut: 1) Memberikan dukungan kepada guru menjadi reflektif dan aktif pelatihan guru di tempat kerja (sekolah); 2) Mengembangkan jalinan yang kuat antara sekolah dan masyarakat, menggunakan metode partisipatori dalam pembelajaran; 3) Memperkenalkan meto-dologi pembelajaran berpusat pada anak dan belajar aktif. Melibatkan anak dalam memecahkan masalah; 4) Menciptakan sistem yang fleksibel yang dapat beradaptasi terhadap perubahan dengan dukungan jaringan yang luas. Menyesuaikan sistem kepada anak bukan anak kepada sistem; 5) Belajar dari keberhasilan pendidikan non/in formal, merancang kurikulum sesuai dengan kebutuhan masyarakat dengan membuka kesempatan yang luas; dan 6) Melibatkan masyarakat, LSM lokal, dan pemerintah dalam pengadaan infrastruktur yang memadahi.

Permasalahan akademik pada menulis permulaan seperti anak lebih suka menyalin, ragu-ragu ketika akan mulai menulis, tidak mampu menulis lebih dari satu kalimat, serta memiliki kesulitan untuk mengikuti topik tertentu dapat dianalisa sebagai berikut. Kemampuan seseorang dalam menulis melibatkan tiga langkah yaitu pramenulis, membuat draf, kemudian mengedit. Tiap-tiap langkah tersebut memberikan kontribusi tersendiri pada kemampuan anak dalam menulis.

Pada dasarnya siswa belajar menulis melalui tahapan tersebut. Tahapan tersebut bersifat hirarki, sehingga akan saling memberikan dampak satu dan lainnya. Tahap pramenulis merupakan tahapan dasar dalam kemampuan seseorang mengekspresikan perasaannya secara tertulis, mengungkapkan gagasan, dan juga menjaga ketertarikan menulis. Oleh sebab itu, guru harus menekankan pengalaman yang mampu membuat anak tertarik dengan bahasa tulisan sebelum nantinya mengenalkan anak dengan tanda baca dan kapitalisasi dalam menulis. Permasalahan yang ditemukan di lapangan akan rendahnya kemampuan menulis siswa lamban belajar dimungkinkan karena masih belum optimalnya pemberian pengalaman pada anak mengingat subjek penelitian masih di kelas bawah. 


\section{PENUTUP}

Berdasarkan hasil penelitian, kesimpulan yang diperoleh dari penelitian ini sebagai berikut: 1) Implementasi pendidikan inklusi memberikan dampak positif terhadap capaian akademik membaca dan aritmatika siswa lamban belajar; 2) Implementasi pendidikan inklusi belum memberikan dampak positif terhadap capaian akademik menulis permulaan siswa lamban belajar.

\section{DAFTAR PUSTAKA}

MacMillan, D. L., Gresham, F. M., Bocian, K. M., \& Lambros, K. M. (1998). Current plight of borderline students: Where do they belong. Education and Training in Mental Retardation and Developmental Disabilities, 33, 8394.

Permen No. 70 tahun 2009. Online. Diakses melalui

http://kelembagaan.ristekdikti.go.id/

wp-

content/uploads/2016/11/PermenNo.-70-2009-tentang-pendidiianinklusif-memiliki-kelainankecerdasan.pdf pada 26 Mei 2017.

UU. No. 20 Tahun 2003. Online. Diakses melalui http://sindikker.dikti.go.id/dok/UU/U U20-2003-Sisdiknas.pdf pada $26 \mathrm{Mei}$ 2017.

Wehmeyer, M.L., Agran, M., \& Hughes, C. (2000). A national survey of teachers' promotion of self-determination and student directed learning. Journal of Special Education, 34, 58-68. 